\title{
Evaluation of the Influence of Bainitic Transformation on some Mechanical Properties of Calcium Treated Cast iron
}

\author{
${ }^{\mathrm{a} U m o r u, ~ L . E ., ~}{ }^{\mathrm{b}}$ Ali, J.A. and ${ }^{\mathrm{a}}$ Afonja, A.A. \\ ${ }^{a}$ Department of Metallurgical and Materials Engineering, \\ Obafemi Awolowo University, Ile-Ife, Nigeria. \\ ${ }^{\mathrm{b}}$ Nigeria Building and Road Research Institute (NIBRRI) \\ Garki, Abuja
}

\begin{abstract}
This work has investigated the effect of austempering variables on hardness, strength and toughness of $0.48 w t$. \% calcium treated cast iron. The iron was subjected to varying austenitizing and isothermal transformation temperatures and times. Samples were austenitized for 15, 30, 45 and 60 minutes at each of the temperatures 850, 875, 900, 925 and 950 degrees centigrade. Also for $950^{\circ} \mathrm{C}$ and 60 minutes of austenitizing conditions, samples of the $0.48 \mathrm{wt}$. \% calcium treated irons were isothermally transformed at 300330,360 and $420^{\circ} \mathrm{C}$ for 2 hours each.

The results of this work show that austenitizing temperature enhances the hardness property of the austempered iron. The Brinell hardness values of austempered iron increased from $275 \mathrm{BHN}$ to $368 \mathrm{BHN}$ after austenitizing for an hour between 850 and $950^{\circ} \mathrm{C}$ respectively. The austenitizing time does not show any significant influence in the same temperature range. The tensile strength increased from $277.5 \mathrm{MPa}$ at the transformation temperature $300^{\circ} \mathrm{C}$ to a maximum of about $430 \mathrm{MPa}$ at $374^{\circ} \mathrm{C}$ and decreased afterwards. The percentage elongation on the other hand, reduced to a minimum of $2.7 \%$ at $360^{\circ} \mathrm{C}$ and increased thereafter with increase in transformation temperature. The austempered microstructures were the accicular lower bainites that are fine for isothermal temperatures below $374^{\circ} \mathrm{C}$ and coarse upper bainites for higher isothermal transformation temperatures.
\end{abstract}

Key words: Austempering, cast iron, calcium, austenitizing, isothermal, transformation, bainites, strength, elongation

\section{INTRODUCTION}

Iron foundry was the nucleus of industrial revolution of the developed nations and is still the foundation for effective industrial development of any nation. The technological demand for high toughness and superior quality components has forced the developed nations to substitute wrought and powder metallurgy components for cast components from conventional gray cast iron. In spite of their inferior mechanical properties in certain engineering uses, the developed nations have not lost sight of the advantages of iron castings over forged products, such as ease of casting of intricate 
components to near-net shape, lower raw materials and overall production cost and possession of certain desirable physical properties.

In order for cast iron products to compete with forged products in applications demanding high strength, the inherent problem of low toughness and ductility associated with cast iron products must be overcome. When graphite is present in the form of nodules, higher toughness and ductility can be achieved in the castings. Additionally, because of the volume of graphite nodules, a ductile iron casting will weigh approximately $10 \%$ less than steel forging if both have exactly the same shape (Warrick et al, 2000). Also, ductile iron castings will provide greater shape flexibility as the result of draft angle requirements and the ability to cast in features through the use of cores. These nodular irons are produced mainly by addition of elements such as magnesium and cerium. Other elements such as calcium, lithium, rare earths have also been identified as having potentials to nodualrize cast iron graphites. The work of Umoru et al (2005) has confirmed calcium as a resourceful graphite nodularizer particularly for the Nigerian Iron Founders. Their research determined the calcium quantity required for optimum nodularization as $0.48 \%$ by weight. Compared with the traditional materials ( $\mathrm{Mg}$ and $\mathrm{Ce}$ ) used for graphite nodularization in iron, calcium is not only cheaper and more readily available in Nigeria, its higher melting point and boiling point make it more suitable for the nodularizing process. While one of the major problems with magnesium is manipulation of the vapour generated during nodularizing, calcium is not subject to this problem. The reason is because $\mathrm{Mg}$ has a boiling point of $1107^{\circ} \mathrm{C}$ which is far less than the melting point of cast iron that is between 1153 and $1400^{\circ} \mathrm{C}$ depending on the carbon content while $\mathrm{Ca}$ has its boiling point as $1372^{\circ} \mathrm{C}$. In addition to exhibiting similar affinity for oxygen and sulphur according to Ellingham diagram, calcium has affinity for other impurities like silicates in iron that perhaps explains why it is able to slag off impurities in iron melts.

Another microstructural parameter that is known to influence the mechanical properties of nodular iron is the structure of the matrix surrounding the free graphite particles. This has been another area of research concentration in recent years particularly with respect to magnesium or cerium graphite nodularized cast irons. Research efforts in this area have been focused on heat treatment and alloy additions to achieve the desired structure. The research and foundry practice in the developed countries in recent years according to Dorazil (1982) and Imasogie, et al (2000) have firmly established the use of isothermal heat treatment to produce bainitic matrix structure (i.e. austempering) as an effective means of obtaining the desired combination of properties.

The technological advances made thus far in the production of graphite nodules in bainitic matrix structures have led to significant improvement in properties and performance. While conventional ductile iron grades have long been used successfully for automobile components, the high strength and toughness of austempered ductile iron offers much greater potential for weight reduced designs (Warrick et al, 2000). It is now possible to use this class of materials for critical engineering components requiring excellent combinations of high strength and ductility (i.e. high toughness). Ductile cast iron is now being used to make pinion and bevel gears, cam and crankshafts in automobile engineering. It is also being used to make tractor and earth moving equipment components, heavy duty cutting knives and railway wagon wheels. 
Having obtained $0.48 \mathrm{wt} . \%$ calcium as that required for maximum nodularization of graphite in iron (Umoru, et al 2005), this work seeks to establish an austempering heat treatment schedule for the inducement of the best combination of mechanical properties in the nodular cast iron with $0.48 \mathrm{wt}$.\% calcium as nodularizer.

\section{EXPERIMENTAL DETAILS}

The 0.48 wt. \% calcium treated iron was prepared according to the procedure in Umoru et al (2005) from gray iron engine block and a grade of ferro-silicon alloy. The tensile test pieces were machined to geometrical specification according to B.S. tensile specification No. 18 (1950) as contained in Monsanto Hounsfield tensometer machine manual. Prior to austempering treatment the surface of the test-pieces were ground on a machine to 600 grit on the same emery paper. Hardness and metallographic specimens were cut from the annealed rods prior to austempering.

Austempering involves basically two processes: solution treatment and isothermal transformation. Each of these processes is identified with two variables, viz. treatment temperature and time. Rossi and Gupta (1981) had once described the austempering process of nodular irons to require the austenitizing variables of 850 to $925^{\circ} \mathrm{C}$ and $2-4$ hours. To determine the suitable combination of the above variables to use for the austempering of the calcium treated iron, twenty samples of the $0.48 \mathrm{wt} . \% \mathrm{Ca}$ treated irons were austenitized at temperatures of $850{ }^{\circ} \mathrm{C}, 875^{\circ} \mathrm{C}, 900{ }^{\circ} \mathrm{C}, 925^{\circ} \mathrm{C}$ and $950{ }^{\circ} \mathrm{C}$ for $15,30,45$ and 60 minutes respectively at each temperature. Throughout the experiments, the transformation conditions were maintained at $350^{\circ} \mathrm{C}$ and 3 hours because according to literature this temperature falls in the bay of the isothermal transformation diagram of the ductile iron and 3 hours will be sufficient to drive the bainite transformation to completion (Rossi and Gupta, 1981). Each of the samples under investigation was cut to the average thickness of the tensile samples, i.e. $3.50 \mathrm{~mm}$ for the purpose of fair inference. The results have been synthesized and used to determine the effect of the temperature and time variables on the strength and the ductility of the austempered iron variables.

A pair each of the tensile samples used for the austempering process was austenitized at the optimum condition determined above and austempered at $300{ }^{\circ} \mathrm{C}, 330$ ${ }^{\circ} \mathrm{C}, 360{ }^{\circ} \mathrm{C}$ and $420{ }^{\circ} \mathrm{C}$ for an austempering time of 2 hours. The tensile properties of the samples were subsequently measured.

The Brinell Hardness accessories of Monsanto type W-tensometer were employed for the hardness tests with results expressed in BHN. The surfaces of austempered samples were all prepared metallographically to 600 grit and cleaned before the hardness test. An average of four impressions was made on each sample and their dimensions measured with the help of the scale attached to the Brinell reading microscope. The mean diameters of indentations were used to obtain the BHN hardness values.

Ten austempered test pieces of the $0.48 \mathrm{wt} . \% \mathrm{Ca}$ treated irons were tested in tension to failure on the tensometer used. The percentages of elongation were subsequently calculated.

The bainitic matrices of the austempered cast irons were microscopically observed using Wild M50 Metallurgical microscope. The universal EPI-Apochromat objective of $40 \mathrm{x}$ and eye-piece of 20x magnifications were used for observing and taking the 
micrographs of the austempered calcium treated irons A Photoautomat MKa and a motor driven 35 magazine were attached to the $\mathrm{HZ}$ phototube of the M50 microscope and used for the photomicrography.

\section{RESULTS}

Prior to investigating the effect of isothermal transformation temperature on the austempered properties of the calcium treated iron produced in this work, the effect of the austenitizing conditions were studied.

Figure 1 shows the graphical plots of the hardness versus austenitizing times for the cast irons austenitized at different temperatures. In general, the graphs show that hardness of the austempered irons increases with solution treatment temperature. The increases for temperatures 850, 875, 900 and 925 degrees centigrade are similar in the sense that they are cyclical. That is, their increases fluctuated around mean values. As for the $950^{\circ} \mathrm{C}$ austenitizing temperature, the increase was gradual and tended to saturate to a hardness value in the austempered iron. Rundman and Klurg (1982) reported an increase in carbon content of austenite from 0.06 to $1.40 \mathrm{wt}$. \% $\mathrm{C}$ in the temperature range 770 to $1100^{\circ} \mathrm{C}$. The quantity of carbide precipitated after austempering has direct relationship with the carbon content of austenite and the final hardness of austempered iron. Accordingly, the increased carbon content of austenite with increase in the austenitizing temperature between 850 and $950^{\circ} \mathrm{C}$ explains the increase in the hardness values shown in Fig.1.

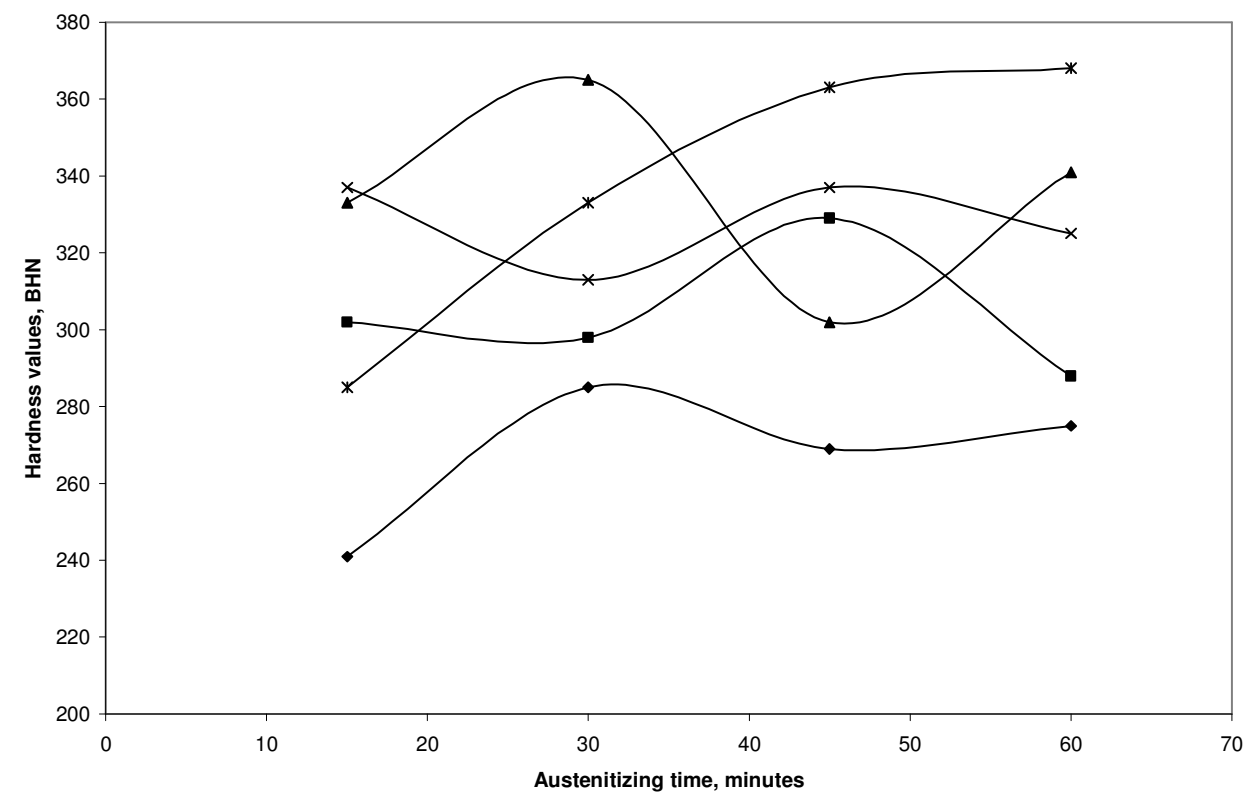

Fig. 1 Effect of time at various austenitizing temperature on $0.48 w t . \%$ Ca-treated cast iron austempered at $350 \mathrm{oC}$ for 3 hours

$\rightarrow-8500 \mathrm{C} \rightarrow-8750 \mathrm{C} \rightarrow-9000 \mathrm{C} \quad * 9250 \mathrm{C} \quad *-950 \mathrm{oC}$

Figure 2 shows the influence of solution treatment time on the austempered calcium treated iron. Plots of hardness versus solutionizing temperatures at the austenitizing times 15, 30, 45, and 60 minutes were used to evaluate the effect 
austenitizing times. The curves in Fig. 2 do not establish any clear relationship between hardness values and the austenitizing times. In other words, the solutionizing time at the gauge thickness level of the samples investigated does not have a significant effect on the austempered properties.

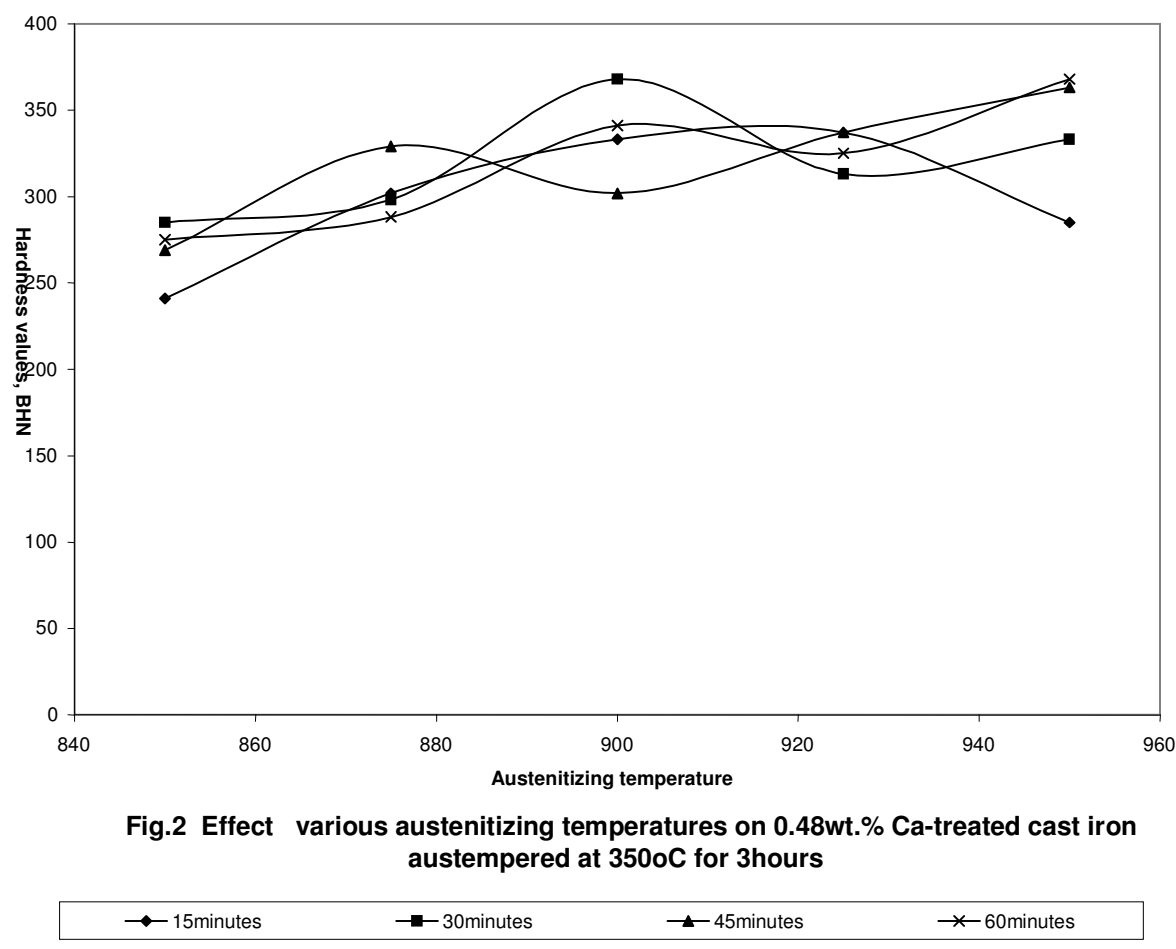

After analyzing the effect of austenitizing conditions on the hardness of calcium treated iron, $950^{\circ} \mathrm{C}$ and 1 hour were chosen as the most appropriate austenitizing conditions for the austempering of the irons produced in this work. This choice corroborates the work of others like Rossi and Gupta (1981).

During austenitizing, the pearlitic zones generally get enough supply of carbon to transform immediately to graphite nodules through diffusion, a process that is both time and temperature dependent (Rajan, et al, 1988). As a result of this, an hour was chosen to austenitize the starting ferritic matrix of the annealed iron in this work at $950^{\circ} \mathrm{C}$. With these solutionizing conditions, the effect of isothermal transformation temperature on some austempered mechanical properties of $0.48 \mathrm{wt} . \%$ calcium has been studied. The results are contained in Figs. 3 and 4 .

Figure 3 shows the variation of tensile strength of the austempered irons with transformation temperatures between 300 and $420^{\circ} \mathrm{C}$. The strength increased initially from an average value of about $277.5 \mathrm{MPa}$ at $300^{\circ} \mathrm{C}$ transformation temperature to about $430 \mathrm{Mpa}$ at $374^{\circ} \mathrm{C}$. With increase in austempering temperature beyond $374^{\circ} \mathrm{C}$ the tensile strength of the iron decreased rapidly to lower values. The temperature of $374^{\circ} \mathrm{C}$ therefore marks the transitional temperature of transformation from the lower bainite regions to the upper bainites. Other researchers have also reported transformation in the neighbourhood of $370^{\circ} \mathrm{C}$ ( Imasogie et al, 2000) . 
The influence of isothermal transformation temperature on average percentage of elongations (ductility) shows that the ductility of the calcium treated iron decreases slightly until about $360^{\circ} \mathrm{C}$ and increases afterward with increase in the transformation temperature (Fig.4).

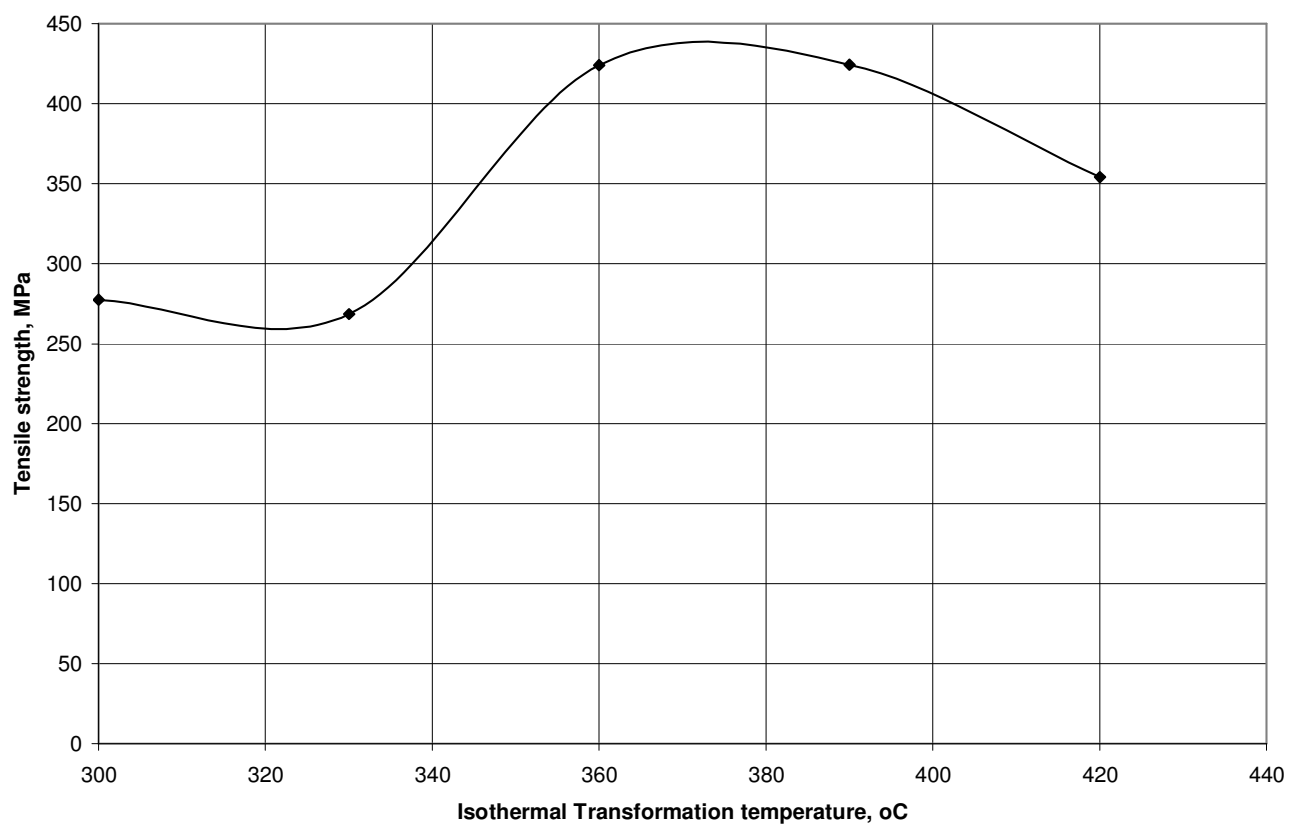

Fig.3 Variation of isothermal transformation temperature with tensile strength of $0.48 \mathrm{wt} . \% \mathrm{Ca}$ treated cast iron after solutionizing at $9200 \mathrm{C}$ for 1 hour and austempered for 2 hours

Figures 5 to 9 show the austempered microstructure of the $0.48 \mathrm{wt} \% \mathrm{Ca}$ treated irons. Figure 5 represents the resultant microstructure after treatment at $950^{\circ} \mathrm{C}$ for an hour and $300^{\circ} \mathrm{C}$ for 2 hours. In a similar manner, Figs. 6 to 9 show the structures after transformation at $330^{\circ}, 390^{\circ}$, and $420^{\circ} \mathrm{C}$, respectively. Even though the magnification of 800x was not enough it can still be seen that the structure of the iron austempered at $420^{\circ} \mathrm{C}$ is coarser than those of $390^{\circ}$ and $360^{\circ} \mathrm{C}$. Similarly, the $300^{\circ} \mathrm{C}$ microstructure is coarser than those of $330^{\circ} \mathrm{C}$ and $360^{\circ} \mathrm{C}$.

\section{DISCUSSION OF RESULTS}

On the basis of the morphological study of bainitic structure in silicon steel and ductile iron, and taking into account the transformation kinetics, the course of transformation of austenite in the bainite region has been divided into three stages (Dorazil, 1982). During the first stage characterized by an average transformation rate, nucleation sets in and ferrite plates begin to grow. The untransformed austenite at this stage gradually becomes enriched with carbon and transform into a considerable amount of martensite on cooling. This structure markedly affects the properties of the austempered iron, resulting in most cases in premature fracture in tension. 


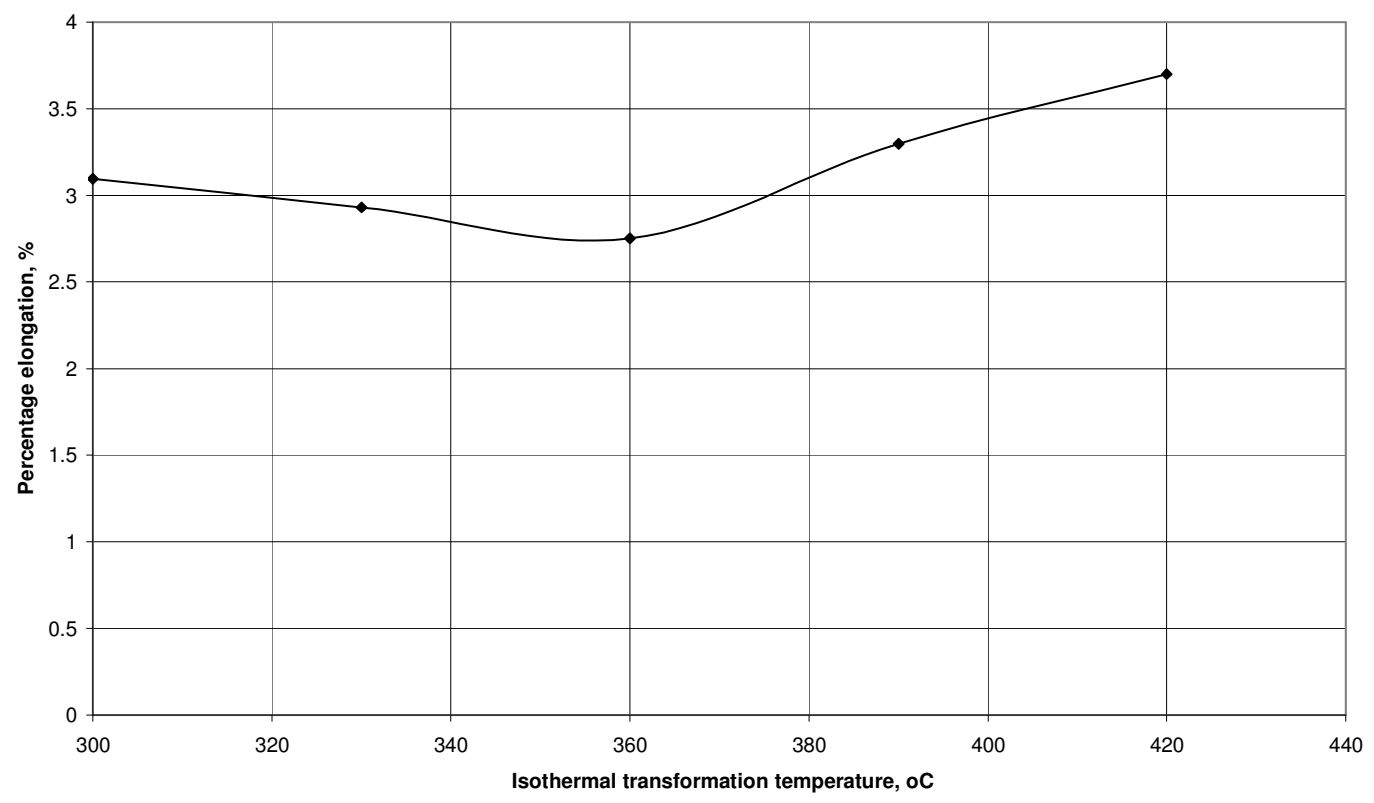

Fig.4 Variation of isothermal transformation temperature with percent elongation of $0.48 \mathrm{wt} . \%$ Ca-treated cast iron after solutionizing at $9200 \mathrm{C}$ for 1 hour and austempered for 2 hours

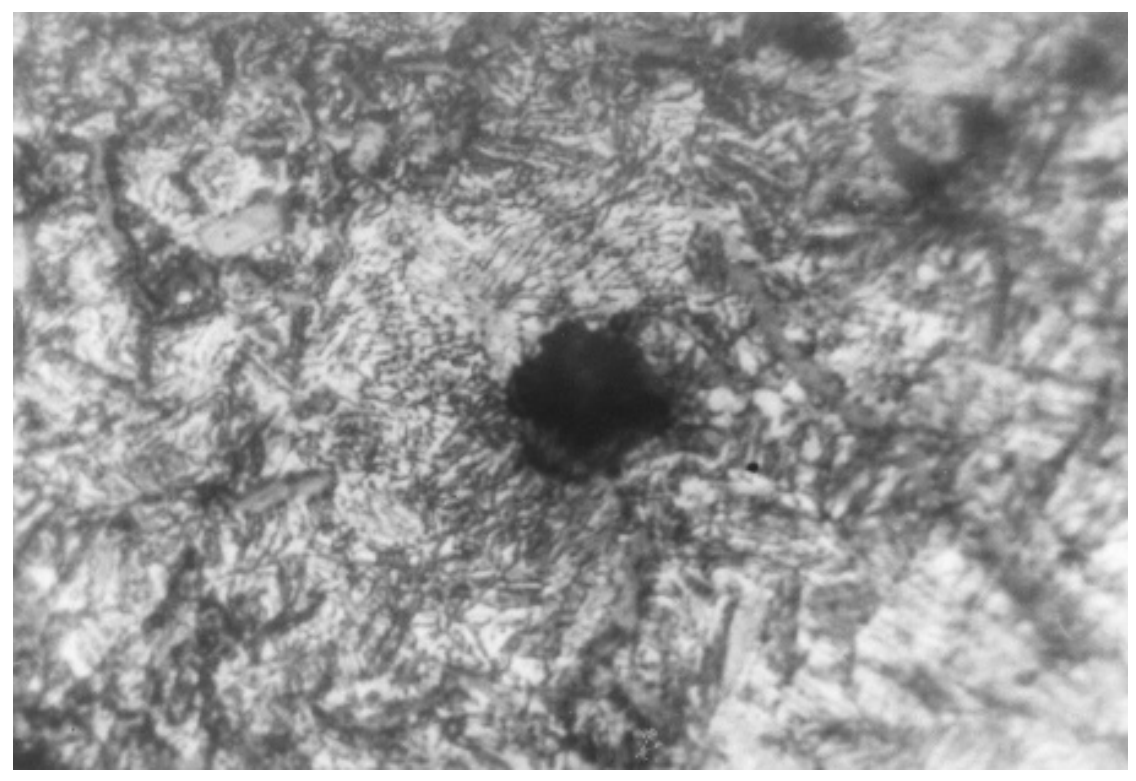

Fig. 5 Micrograph of austempered $0.48 \mathrm{wt} . \% \mathrm{Ca}$ treated iron. Austempering condition= $950^{\circ} \mathrm{C} / 1 \mathrm{hr}+300^{\circ} \mathrm{C} / 2 \mathrm{hrs}+$ air cooling; acicular structure=bainites; light areas=retained austenite and Dark spots=graphite nodules. Picral etached. x 800 


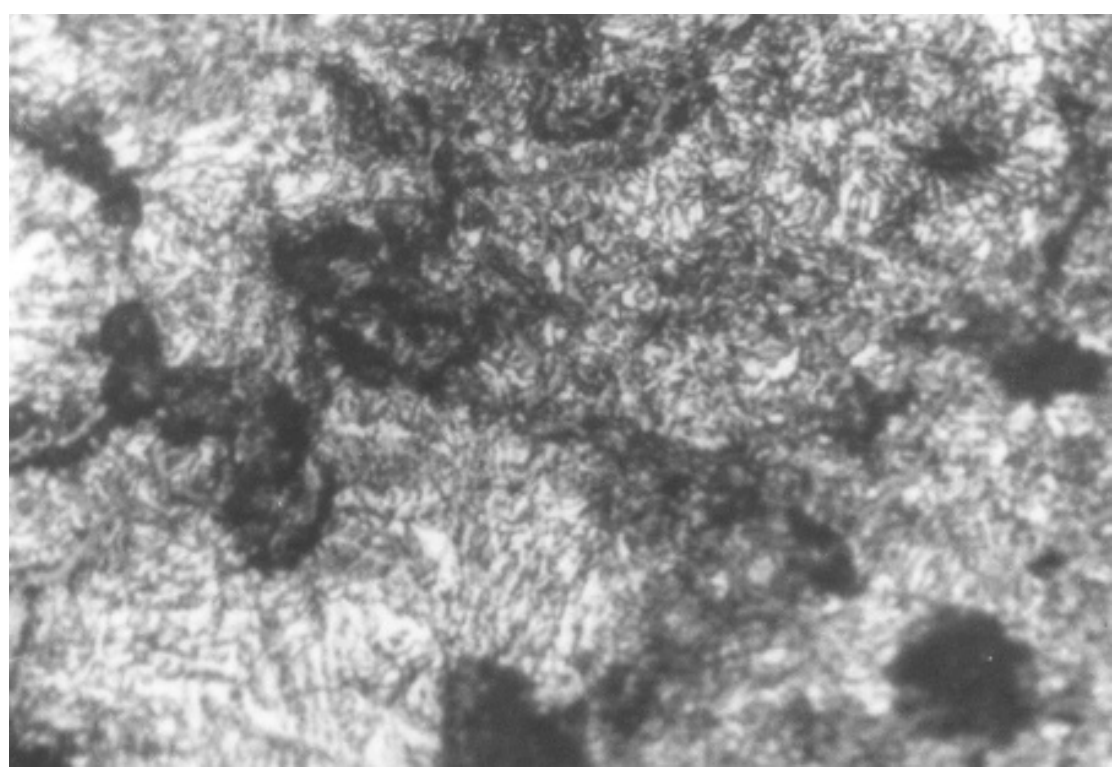

Fig. 6 Micrograph of austempered $0.48 \mathrm{wt} . \% \mathrm{Ca}$ treated iron. Austempering condition= $950^{\circ} \mathrm{C} / 1 \mathrm{hr}+330^{\circ} \mathrm{C} / 2 \mathrm{hrs}+$ air cooling; acicular structure=bainites; light areas=retained austenite and Dark spots=graphite nodules. Picral etached. x 800

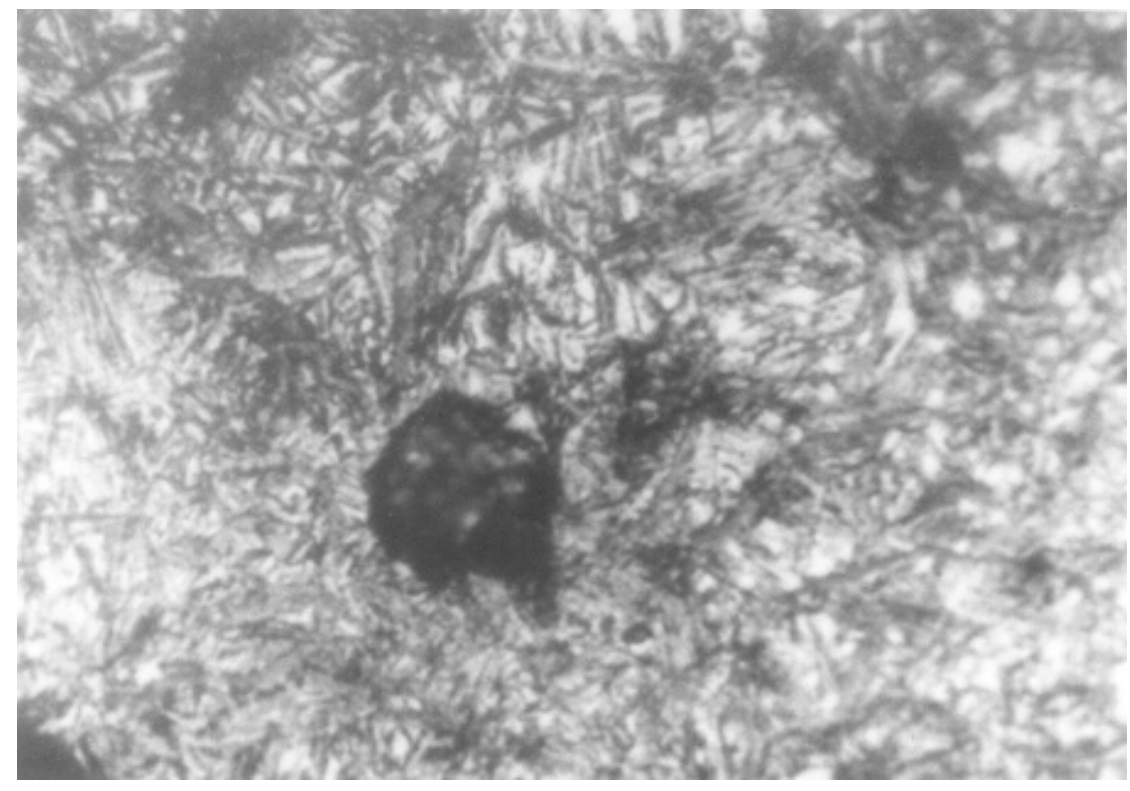

Fig. 7 Micrograph of austempered $0.48 \mathrm{wt} . \% \mathrm{Ca}$ treated iron. Austempering condition= $950^{\circ} \mathrm{C} / 1 \mathrm{hr}+360^{\circ} \mathrm{C} / 2 \mathrm{hrs}+$ air cooling; acicular structure=bainites; light areas=retained austenite and Dark spots=graphite nodules. Picral etached. x 800 


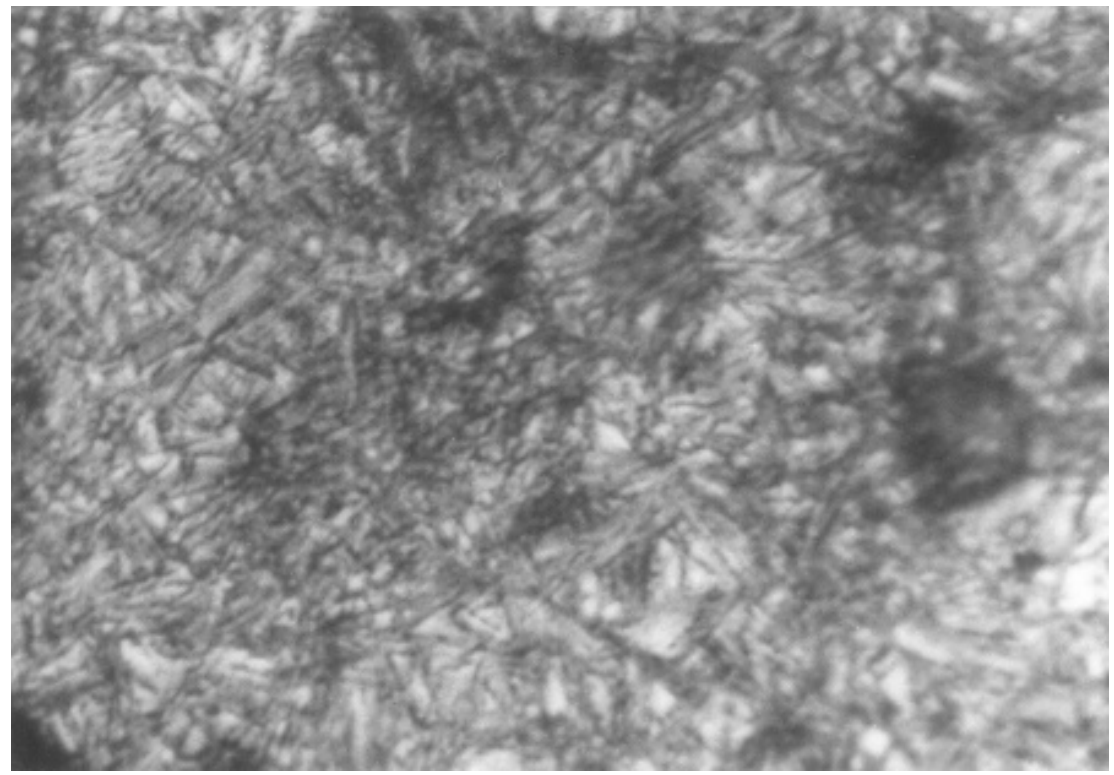

Fig. 8 Micrograph of austempered $0.48 \mathrm{wt} . \% \mathrm{Ca}$ treated iron. Austempering condition= $950^{\circ} \mathrm{C} / 1 \mathrm{hr}+390^{\circ} \mathrm{C} / 2 \mathrm{hrs}+$ air cooling; acicular structure=bainites; light areas=retained austenite and Dark spots=graphite nodules. Picral etached. x 800

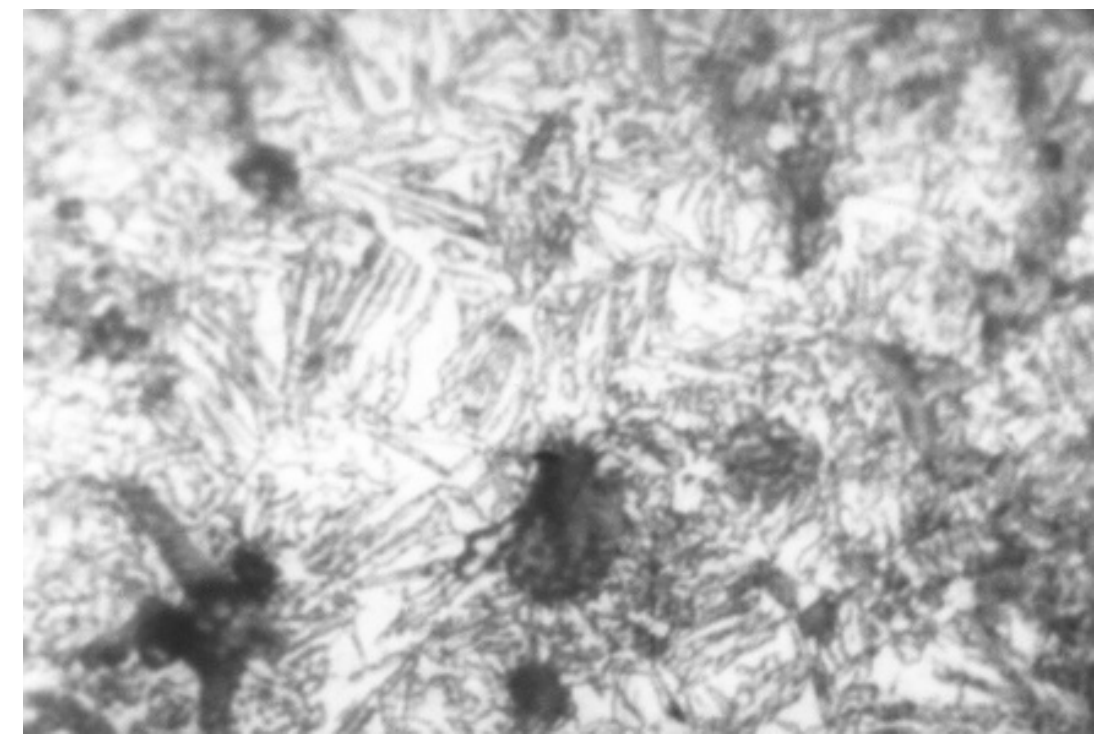

Fig.9 Micrograph of austempered $0.48 \mathrm{wt} . \% \mathrm{Ca}$ treated iron. Austempering condition= $950^{\circ} \mathrm{C} / 1 \mathrm{hr}+420^{\circ} \mathrm{C} / 2 \mathrm{hrs}+$ air cooling; acicular structure=bainites; light areas=retained austenite andDark spots $=$ graphite nodules. Picral etached. $\mathrm{x} 800$

In the second stage, reaction rate is slow and transformation continues mainly by lateral growth of bainitic ferrite plates. The untransformed austenite becomes enriched with carbon to a concentration which does not allow martensite to form on subsequent cooling. 
The third stage is characterized by increased average transformed ferrite plates and reduced portions of retained austenite in the structure. The mixture of ferrite and carbide found in areas where bainitic ferrite plates and carbide grow into each other is said to be indicative of austenite transformation in the form of the eutectoid reaction, in which the carbide phase is the leading one. The carbide phase increases with increase in the carbon content of austenite.

According to Rundman (1983) the carbon content of austenite varies from $0.60 \% \mathrm{C}$ at $770^{\circ} \mathrm{C}$ to about $1.4 \% \mathrm{C}$ at $1100^{\circ} \mathrm{C}$. This results in the increase in carbide phase of the ductile iron with an increase in the austenitizing temperature after transformation at a particular temperature and time. But carbide is a hard phase, its hardness increases the austempered hardness of nodular iron as the amount of carbide increases. Thus, it can be rightly inferred from the effect of solutionizing temperature on the quantity of carbide phase in austempered matrix that the hardness of the austempered iron should increase with austenitizing temperature. This is evident in the trend shown in the result of this work as the hardness of the austempered iron increases with the austenitizing temperatures $850^{\circ}, 875^{\circ}, 925^{\circ}$, and $950^{\circ}$ centigrade respectively.

The variation of tensile strength with isothermal transformation temperatures is shown in Fig.3. The strength increased initially up to a value of about $430 \mathrm{MPa}$ at $374^{\circ} \mathrm{C}$. This simply marks $374^{\circ} \mathrm{C}$ as the transitional austempering temperature from lower bainite to the upper bainites. About $370^{\circ} \mathrm{C}$ is reported by Harding (1986) as the transition period in nodular irons.

From the continuous time temperature transformation diagram for unalloyed irons it can be seen that for transformation in regions close to the Ms point, the start and finish of bainite reaction is drastically delayed. What this implies in effect is that at the end of the two hours of transformation allowed in this project, the austempered iron was probably in the first stage of transformation; so that on cooling, the carbon enriched austenite transformed into martensite, leading to premature fracture in tension (Rossi and Gupta, 1981). This behaviour accounts for the lower values of the tensile strength (277.5 $\mathrm{Mpa}$ ) of the specimen austempered at below $374^{\circ} \mathrm{C}$.

With increase in the transformation temperature following the slope of TTT diagram before the nose of the curve, the start and finish of transformation decrease accordingly leading probably to the approach of the second stage of bainite transformation given the same 2 hours transformation time. The second stage according to Rossi and Gupta (1981) is characterized by maximum tensile strength in the austempered iron. This explains the increase in strength of the iron up to a maximum at the transformation temperature of $374^{\circ} \mathrm{C}$. The subsequent fall in the tensile strength and rise in the percentage elongation in regions above $374^{\circ} \mathrm{C}$ (Figures 3 and 4) is explainable from the standpoint of upper bainite morphology.

In the region between $374^{\circ} \mathrm{C}$ and the nose of the CCT - diagram the bainitic ferrites undergo increased rate of lateral growth (Pickering, 1967). This is due to the favourable temperature condition that enhances increased rate of diffusion of carbon into the austenite phase (Gulaev, 1980). This gives rise to increase in size of ferrite which 
according to Hall and Petch relation (Rajan et al, 1988) results in reduced tensile strength, in accordance with the following equation

$\begin{array}{lll}\mathrm{s}_{\mathrm{i}} & = & \mathrm{s}_{0} \quad+\quad \mathrm{kd}^{-1 / 2} \quad \ldots \ldots \ldots \ldots \ldots \ldots(1) \\ & & \\ \mathrm{s}_{\mathrm{i}} & - & \text { represents the tensile strength, } \\ \mathrm{s}_{0} & - & \text { the strength to overcome internal friction } \\ \mathrm{d} & - & \text { the grain size, and } \\ \mathrm{k} & - & \text { a constant }\end{array}$

Figures 7 and 9 show the different ferrite structures at $360^{\circ}$ and $420^{\circ}$, respectively. The feature of larger ferrite grains at $420^{\circ} \mathrm{C}$ (Upper bainite) is in agreement with the above definition.

When viewed from another metallurgical standpoint, the corresponding decrease in tensile strength and increase in percentage elongation of the austempered $0.48 \mathrm{wt} . \% \mathrm{Ca}$ treated iron above $374^{\circ} \mathrm{C}$ can be attributed to the retained austenite in the micrographs of Figs. 8 and 9 (light background). The austenite structure is the closest packed structure with 12 slip systems. And hence is responsible for the high toughness in the upper bainite.

\section{Conclusions}

The following conclusions can be drawn from the results of this study:

1. The hardness property of austempered calcium treated iron is significantly influenced by austenitizing temperature and not by austenitizing time between 850 and $950^{\circ} \mathrm{C}$.

2. The hardness values of the austempered calcium treated iron are comparable with those of other austempered ductile iron in the literature.

3. The hardness of the austempered cast irons increases with austenitizing temperature from $275 \mathrm{BHN}$ at $850^{\circ} \mathrm{C}$ to $368 \mathrm{BHN}$ at $950^{\circ} \mathrm{C}$. The tensile strength of the same austempered iron varied with the isothermal transformation temperature (ITT) as the strength increased from $277.5 \mathrm{MPa}$ at $300^{\circ} \mathrm{C}$ ITT to a maximum value of $430 \mathrm{MPa}$ at $374^{\circ} \mathrm{C}$ and thereafter decreased.

4. The ductility of the $0.48 \mathrm{wt} . \% \mathrm{Ca}$ iron as measured by percentage elongation decreased with isothermal transformation temperature to a minimum value of $2.7 \%$ at about $360^{\circ} \mathrm{C}$ and increased afterwards to higher values.

5. The microstructures of the bainites formed from the austempering process were finer at isothermal transformation temperatures lower than $374^{\circ} \mathrm{C}$ and coarser with some retained austenite content at higher temperatures. 


\section{REFERENCES}

Dorazil, E. (1982) Influence of heat treatment conditions and chemical composition on the mechanical properties of Low Alloyed Austempered Nodular Cast iron, Giesserei Praxis, No 19, $303-310$.

Gulaev , A (1980). Physical Metallurgy, Vol. 1. $5^{\text {th }}$ Edition MIR Publishers Moscow. Harding. R.A. (1986). Effect of metallurgical variables on austempered ductile irons, Metals and Materials, 65-70.

Imasogie, B.I., Afonja, A.A. and Ali, J.A. (2000). Properties of ductile cast iron nodularized with multiple calcium-magnesium based master alloy, Materials Science and Technology, 16, 194-201

Pickering, F.B (1967) Mechanism of Bainite Formation in the Low Alloy Steel containing up to 0.40 wt. \% Carbon, Transformation and Hardenability in Steels, Climax Molybdenum Co. Ann. Arbor Michigan

Rajan , T.V; Sharma C.P. ; Sharma, Ashok (1988), Heat Treatment -Principles and Techniques Prentice - Hall of India Private Limited,

Rossi, T.S and Gupta, B.K (1981) Austempering of nodular cast iron Automobile component: Metal Progress Vol. 119, No 5, 25 - 31

Rundman, K.B. and Klurg, R.C (1982) An X-ray and Metallographic study of an Autempered Ductile cast Iron Transaction of the American Foundrymen's Society, Vol. 90, $499-508$.

Umoru, L.E.; Ali, J.A.; and Afonja, A.A. (2005) Effect of calcium on the degree of nodularisation of graphite in cast iron, NSE Technical Transactions, 40,.2, 33-42.

Warrick, R.J.; Althoff, P.; Druschitz, A.P.; Lemke, J.P.; Zimmerman, K.; Mami, P.H. and Rackers, M.L.(2000) Austempered Ductile Iron castings for Chasis Applications. Society of Automotive Engineers Inc. 